Brit. F. vener. Dis. (1968), 44, 193.

\title{
LYTIC EFFECT OF TRYPSIN, LYSOZYME, AND COMPLEMENT ON Treponema pallidum*
}

BY

\author{
R. H. JONES, T. A. NEVIN, W. J. GUEST, AND L. C. LOGAN \\ From the Department of Epidemiology, School of Public Health, University of Michigan, Ann Arbor, \\ Michigan 48104, and the Venereal Disease Research Laboratory, Venereal Disease Program, \\ National Communicable Disease Center, Bureau of Disease Prevention and Environmental Control, Public Health \\ Service, U.S. Department of Health, Education, and Welfare, Atlanta, Georgia 30333, U.S.A.
}

The lysis of several strains of cultured spirochaetes, during incubation in guinea-pig serum, is dependent upon the presence of active complement and lysozyme (Nevin and Guest, 1967). Treponema pallidum, however, is not lysed readily in guineapig serum, although motile cells are immobilized more rapidly when crystalline lysozyme is added to suspensions containing serum from syphilitics and active guinea-pig serum (Kent and deWeerdt, 1963; Metzger, Hardy, and Nell, 1961). Similarly, several varieties of Treponemataceae are disrupted by the action of pepsin and trypsin (Bradfield and Cater, 1952; Swain, 1955) whereas T. pallidum, while susceptible to pepsinization, apparently loses only an outer covering as a result of tryptic digestion (Swain, 1955).

Evidently, either lysozyme or trypsin can cause some action adverse to $T$. pallidum. Therefore, the possibility was explored of effecting lysis by using both enzymes, or by using some pre-treatment that would render the cells more susceptible to enzymatic attack (Noller and Hartsell, 1961). There was also an opportunity to relate the effect of some of the conditions necessary for lysis to observable morphological changes.

\section{Methods and Material}

Nichols strain of $T$. pallidum was propagated intratesticularly in rabbits. Upon development of an orchitis (8-11 days) the cells were harvested by mincing each testis, shaking the minced tissues in $15 \mathrm{ml}$. of $0.033 \mathrm{M}$ di-potassium phosphate buffer $(\mathrm{pH} 7 \cdot 3)$ for 30 minutes at room temperature, and collecting the fluid portion. Gross testicular debris was removed by centrifugation at $500 \times \mathrm{g}$ for 10 minutes, leaving the bulk of the spirochaetes suspended in the supernatant fluid. The organisms in portions of the suspensions were washed once by centrifugation at $15,000 \times \mathrm{g}$, the supernatant discarded, and the cells re-suspended in fresh phosphate buffer. The suspensions, washed or unwashed, were adjusted so that each portion contained about $10-15 \times 10^{6}$ cells per $\mathrm{ml}$.

Fresh guinea-pig blood was obtained from young

*Received for publication January 21, 1968. healthy animals by cardiac puncture. The serum was separated, assayed for complementary activity, and stored at $-20^{\circ} \mathrm{C}$. The average complement level was 1,350 haemolytic units per ml. Complement was inactivated by heating at $56^{\circ} \mathrm{C}$. for 30 minutes or by the addition of $25 \mu$ moles of ethylenediaminetetracetate disodium (EDTA) per ml. (Levine, Cowan, Osler, and Mayer, 1953).

Washed and unwashed spirochaete suspensions were stored overnight at room temperature, or in the refrigerator at about $4^{\circ} \mathrm{C}$., or in the freezer at $-20^{\circ} \mathrm{C}$. Samples of each of the washed-cell suspensions were incubated at $37^{\circ} \mathrm{C}$. for 60 minutes with active, or heatinactivated (56 C; $30 \mathrm{~min}$.), or EDTA-inactivated guinea-pig serum. A sample of serum containing equimolar amounts of EDTA and $\mathrm{Ca}++$ was used also, as a control for the EDTA inactivation, and a suspension of cells without added serum served to control any nonserum mediated changes. A ratio of $0.3 \mathrm{ml}$. suspension to $0.2 \mathrm{ml}$. serum was used. Similar amounts of unwashed cell suspensions were incubated in parallel with active serum and without added serum.

Trypsin (Worthington Biochemical Co., Freehold, N. J.) and lysozyme (Mann Research Laboratories, New York, N. Y.) in buffered N-butanol $(0.033 \mathrm{M}$ phosphate, $\mathrm{pH} 7 \cdot 3$ ), as suggested by the work of Noller and Hartsell (1961), were added to $0.3 \mathrm{ml}$. samples of suspensions of freshly-extracted washed spirochaetes and to similar samples of unwashed spirochaetes. The final volume, $0.5 \mathrm{ml}$., contained $200 \mu \mathrm{g}$. of each enzyme, and 2 per cent. $\mathrm{v} / \mathrm{v}$ of $\mathrm{N}$-butanol. The mixtures were incubated at $45^{\circ} \mathrm{C}$. for 45 minutes. In addition, the possibility of lytic action by either of the enzymes or by the alcohol separately, or in the several combinations, was studied. Further, the lytic action of a combination of EDTA and lysozyme, with and without added N-butanol, was determined. Enough EDTA was added to yield a final concentration of $12 \mu \mathrm{M}$ per $0.5 \mathrm{ml}$. When guinea-pig serum $(0.2 \mathrm{ml}$.) was added after the first incubation, the mixtures were re-incubated at $37^{\circ} \mathrm{C}$. for $30 \mathrm{~min}$.

The extent of lysis was estimated from the number of intact cells per 100 still recognizable spirochaetes under darkfield illumination at $\mathbf{4 5 0}$ diameters. It is reported as a percentage of intact cells (Nevin and Guest, 1967).

Immunofluorescent tests were carried out with commercially obtained globulin-isothiocyanate conjugates of 
anti-rabbit globulin prepared from the sera of suitably immunized goats (Microbiological Associates, Bethesda, Md.). The conjugate was absorbed with a preparation of Reiter treponemes (Deacon and Hunter, 1962), diluted 1:16 with phosphate buffered saline (Communicable Disease Center, 1964), and applied directly to acetonefixed smears of the $T$. pallidum suspensions.
Electron micrographs were made of untreated cells and cells that had been treated by each of the means which increased susceptibility to lysis. The cells were fixed by adding 1 volume of 1 per cent. buffered osmic acid (Caulfield, 1957) to 4 volumes of cell suspension, and then negatively stained by adding $1 \mathrm{ml}$. of a 2 per cent. solution of phosphotungstic acid ( $\mathrm{pH} \mathrm{7.4)}$ to $1 \mathrm{ml}$.

Fig. 1.-Electron micrographs showing the effects of washing, trypsinizing, and lysozyme treatment on Treponema pallidum. All the cells shown were fixed in osmic acid and prepared for negative contrast with phosphotungstic acid.

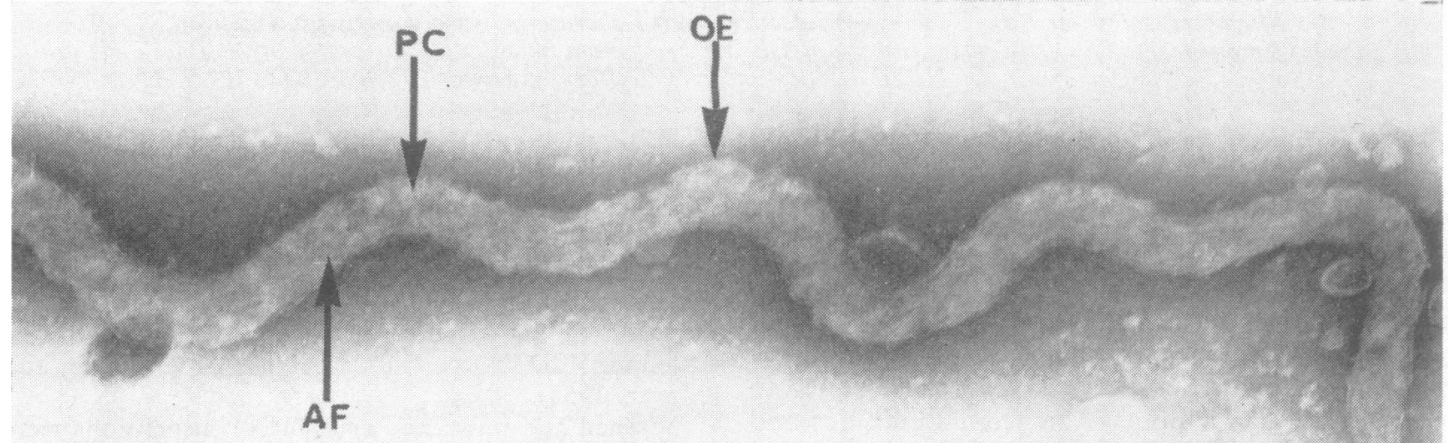

(a) An unwashed cell. $\times 54,000$. Details of the cell appear indistinct, although it is in good focus. Note that the outer envelope (OE) and the protoplasmic cylinder (PC) can be differentiated easily, and that portions of the axial fibrils (AF) can be seen, albeit rather poorly.

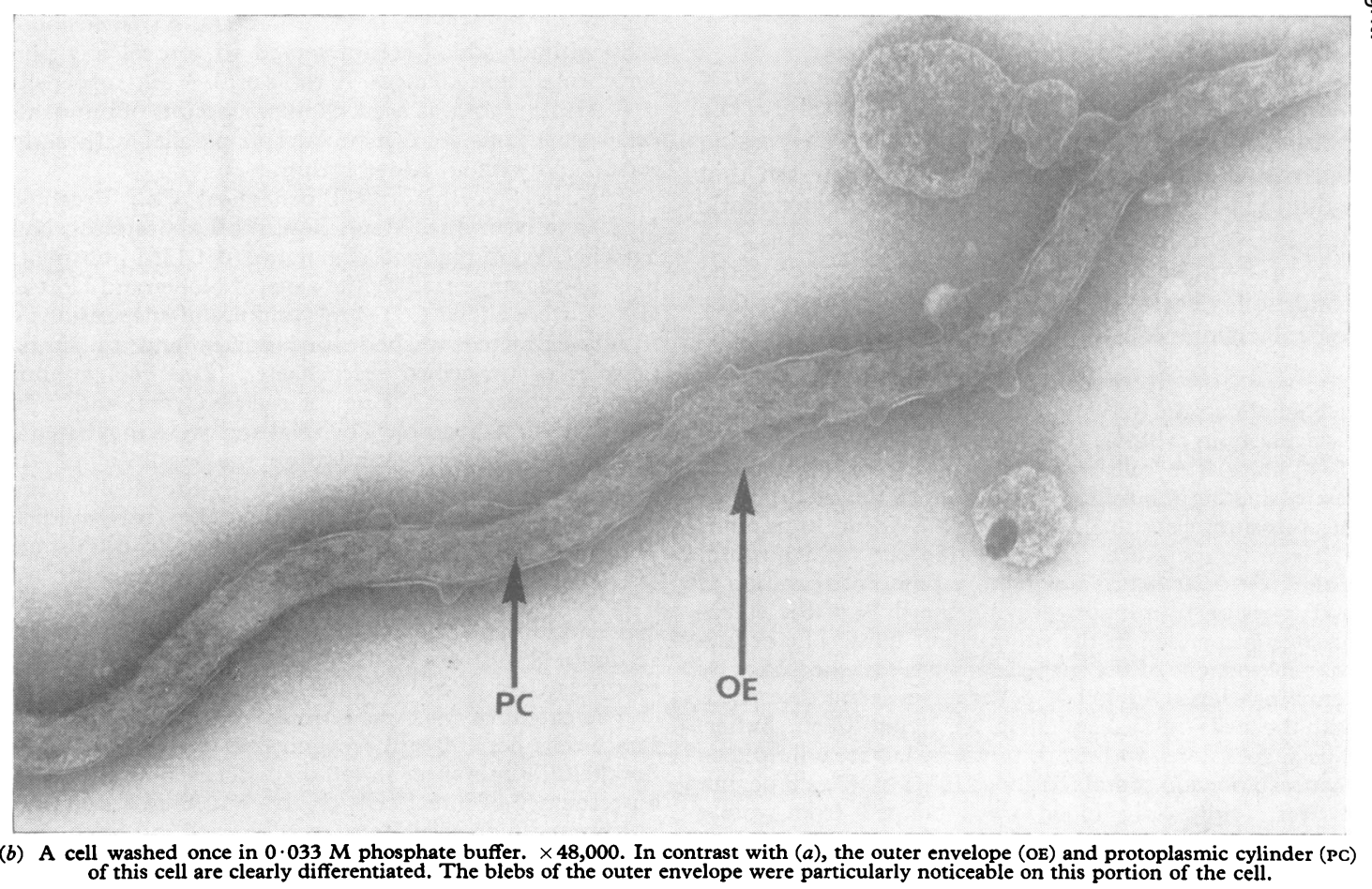

of this cell are clearly differentiated. The blebs of the outer envelope were particularly noticeable on this portion of the cell. 
of suspension (Kellenberger, Ryter, and Sechaud, 1958; Listgarten, Loesche, and Socransky, 1963). Thereafter, the suspensions were spread on formvar-coated stainlesssteel grids, and examined thoroughly with the JEM $6 \mathrm{~A}$ (JEOL, Japan) electron microscope with doublecondenser lens illumination. Initial magnification ranged from $\times 4,000$ to $\times 32,000$. Additional magnification was obtained by photographic enlargement.

\section{Results}

Unwashed spirochaetes fluoresced measurably when tested with adsorbed goat anti-rabbit-globulin conjugate by immunofluorescent means. On a scale of negative to 1 plus up to 4 plus, a reading of 1 plus was usual. Readable fluorescence was not obtained with washed cells when tested by the same method. Similarly, the loss of a covering material relatively dense to the electron beam as a result of washing may be seen in a comparison of Fig. 1(a) with Fig. $1(b)$; the surface character of the cell in Fig. $1(b)$ is more clearly defined.
Suspensions of washed spirochaetes which had been freshly prepared and stored overnight at room temperature or in the refrigerator at about $4^{\circ} \mathrm{C}$. were not affected when active guinea-pig serum was added. However, suspensions that had been stored overnight at $-20^{\circ} \mathrm{C}$. underwent extensive lysis. When heat-inactivated or EDTA-inactivated guinea-pig sera were mixed with susceptible cells, lysis was markedly reduced, whereas the inclusion in active serum of equimolar amounts of EDTA and $\mathrm{Ca}++$ permitted lysis to occur (see Table I, overleaf). Darkfield examination revealed no visible damage to the spirochaetes before the addition of the active guinea-pig serum. Lysozyme, used by itself on spirochaetes which had been frozen, caused no visible damage either. However, the electron micrograph of an otherwise untreated frozen cell [Fig. $1(c)$ ] shows the outer envelope to have been swollen and stretched.

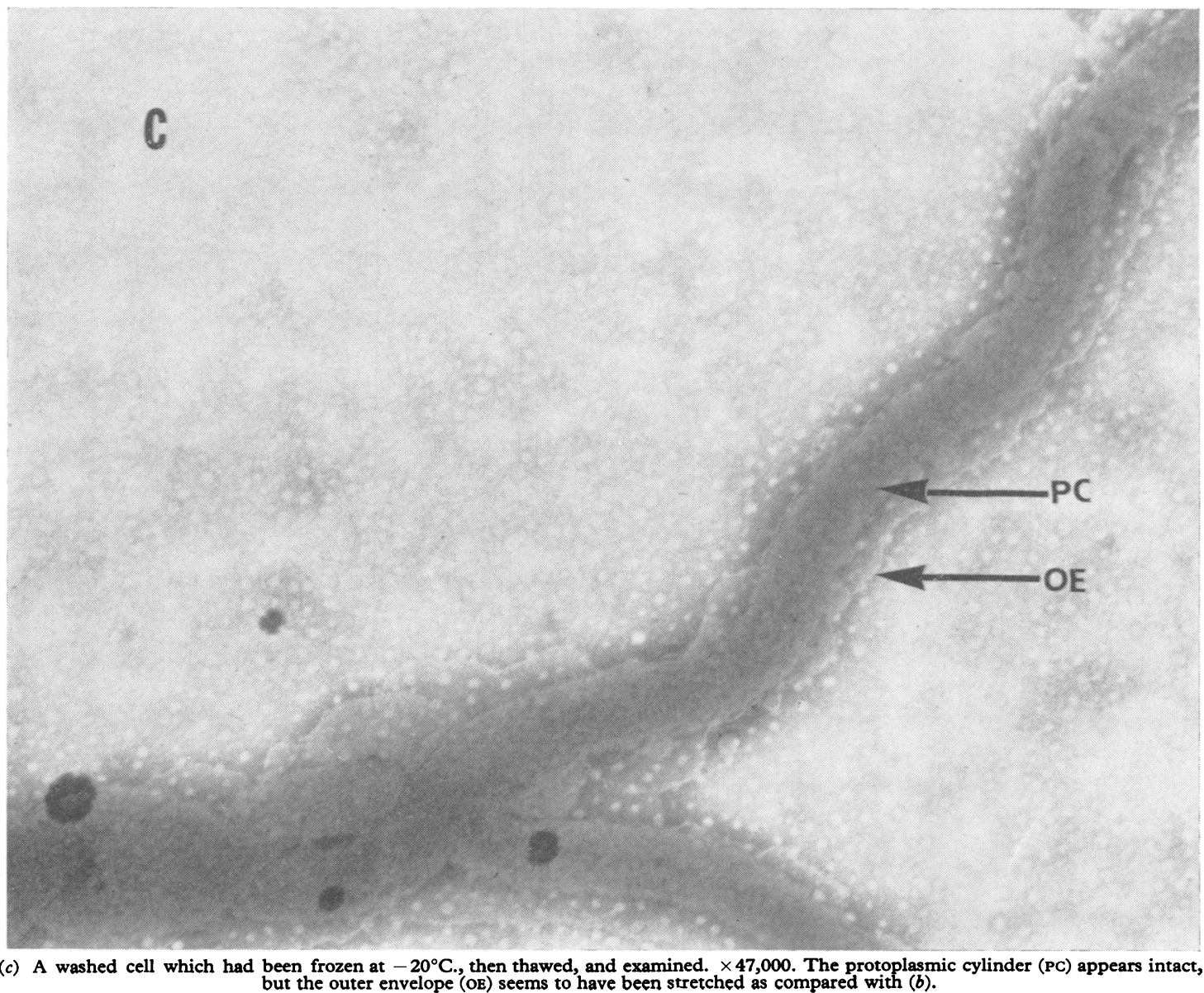
but the outer envelope (OE) seems to have been stretched as compared with (b). 
TABLE I

EFFECT OF FREEZING AND COMPLEMENT ON THE LYSIS OF T. PALLIDUM IN GUINEA-PIG SERUM ${ }^{a}$

\begin{tabular}{|c|c|c|c|c|}
\hline \multirow{2}{*}{\multicolumn{2}{|c|}{ T. pallidum Suspensions }} & \multicolumn{3}{|c|}{$\begin{array}{l}\text { Percentage Intact Cells } \\
\text { after } 1 \mathrm{hr} \text { at } 37^{\circ} \mathrm{C} \text {. }\end{array}$} \\
\hline & & Room ${ }_{\text {Temp. }}$ & $4^{\circ} \mathrm{C} . b$ & $-20^{\circ} \mathrm{C} \cdot b$ \\
\hline Washed & $\begin{array}{l}\text { 1. With untreated serum } \\
\text { 2. With treated serum } c \\
\text { 3. With EDTA-inactivated } \\
\text { serum } \\
\text { 4. With serum, EDTA, } \\
\text { and Ca }++ \\
\text { 5. Without serum }\end{array}$ & $\begin{array}{r}88 \\
100 \\
100 \\
100 \\
100\end{array}$ & $\begin{array}{r}94 \\
100 \\
100 \\
100 \\
100\end{array}$ & $\begin{array}{l}22 \\
99 \\
85 \\
30 \\
94\end{array}$ \\
\hline Unwashed & $\begin{array}{l}\text { 1. With untreated serum } \\
\text { 2. Without serum }\end{array}$ & $\begin{array}{l}100 \\
100\end{array}$ & $\begin{array}{r}98 \\
100\end{array}$ & $\begin{array}{r}91 \\
100\end{array}$ \\
\hline
\end{tabular}

$a$ Averaged data from four experiments.

$b$ Stored for $16 \mathrm{hrs}$.

c $56^{\circ} \mathrm{C}$; $30 \mathrm{~min}$.

Suspensions of washed cells either freshly prepared or stored overnight in the refrigerator were readily lysed by a combination of $200 \mu \mathrm{g}$. per tube of trypsin and $200 \mu \mathrm{g}$. per tube of lysozyme in phosphate buffer at $\mathrm{pH} .7 \cdot 3$ during incubation at $45^{\circ} \mathrm{C}$. for 45 minutes. $\mathrm{N}$-butanol enhanced this reaction, as reported by Noller and Hartsell (1961). In preliminary experiments in which $20 \mu \mathrm{g} . / \mathrm{ml}$. of each enzyme were used as suggested by the work, of these authors, no lysis of spirochaetes was observed during the incubation period used.

When untreated guinea-pig serum was added to suspensions which had been incubated with lysozyme, or lysozyme and N-butanol, extensive lysis also occurred. Cell suspensions pre-incubated with lysozyme, to which EDTA-inactivated serum was added, or suspensions pre-incubated with EDTA and lysozyme to which active guinea-pig serum was added, did not lyse readily. However, suspensions that had been pre-incubated with EDTA, lysozyme, and N-butanol were almost completely lysed when active serum was added. Trypsin, lysozyme, N-butanol, or guinea-pig serum each used separately, did not cause appreciable lysis as determined by darkfield microscopy. Unwashed cells did not lyse under the most drastic of the conditions described. These experiments are summarized in Table II (opposite).

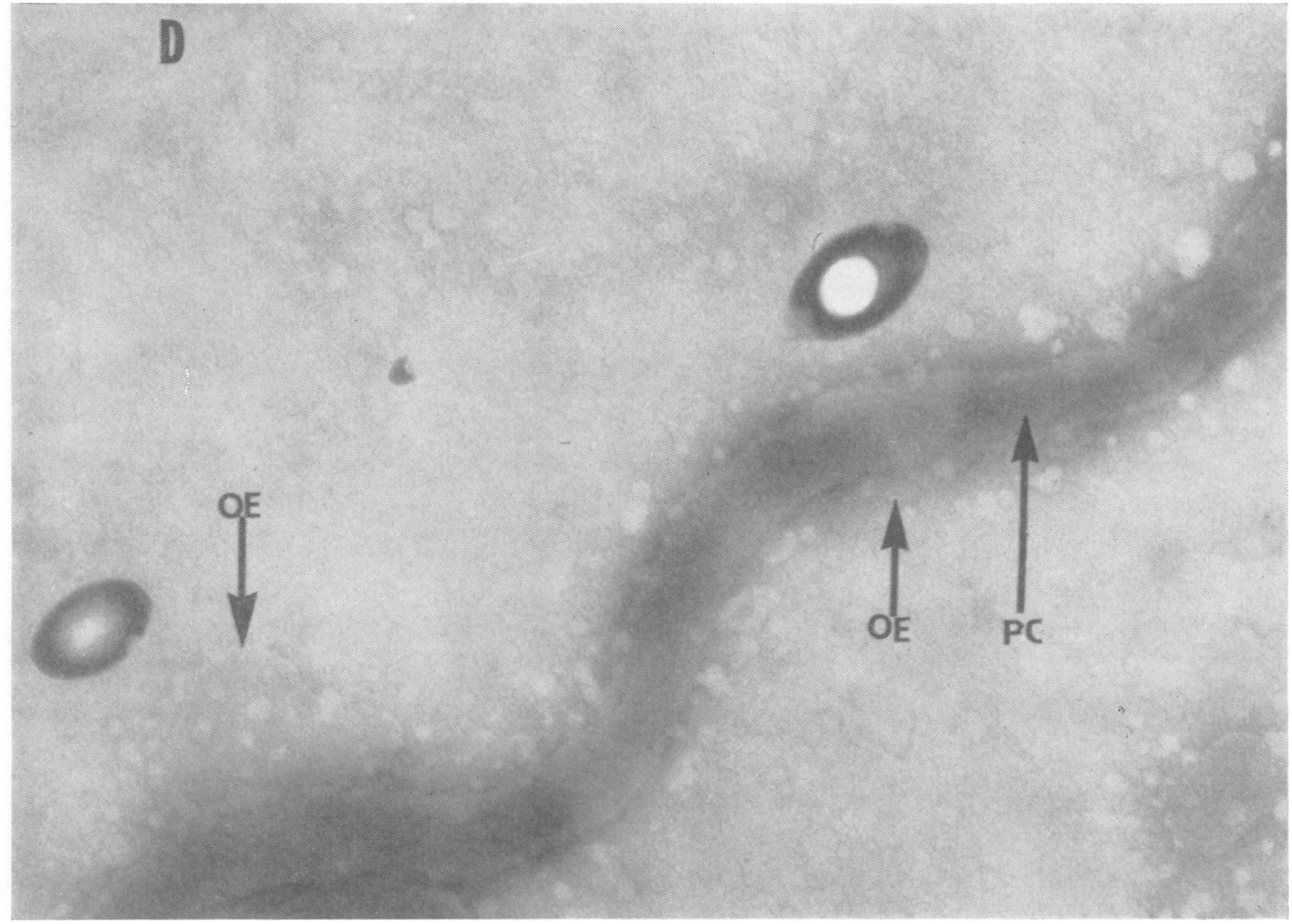

(d) A washed cell which had been incubated with trypsin at $45^{\circ} \mathrm{C}$. for 45 minutes. $\times 52,800$. The trypsinized cell has no discernible outer envelope; however, there is no evidence of damage to the protoplasmic cylinder (PC). Remnants of the envelope (OE) may be seen at several points. 
TABLE II

LYTIC ACTION OF TRYPSIN, LYSOZYME, N-BUTANOL, AND GUINEA-PIG SERUM ON T. PALLIDUM ${ }^{a}$

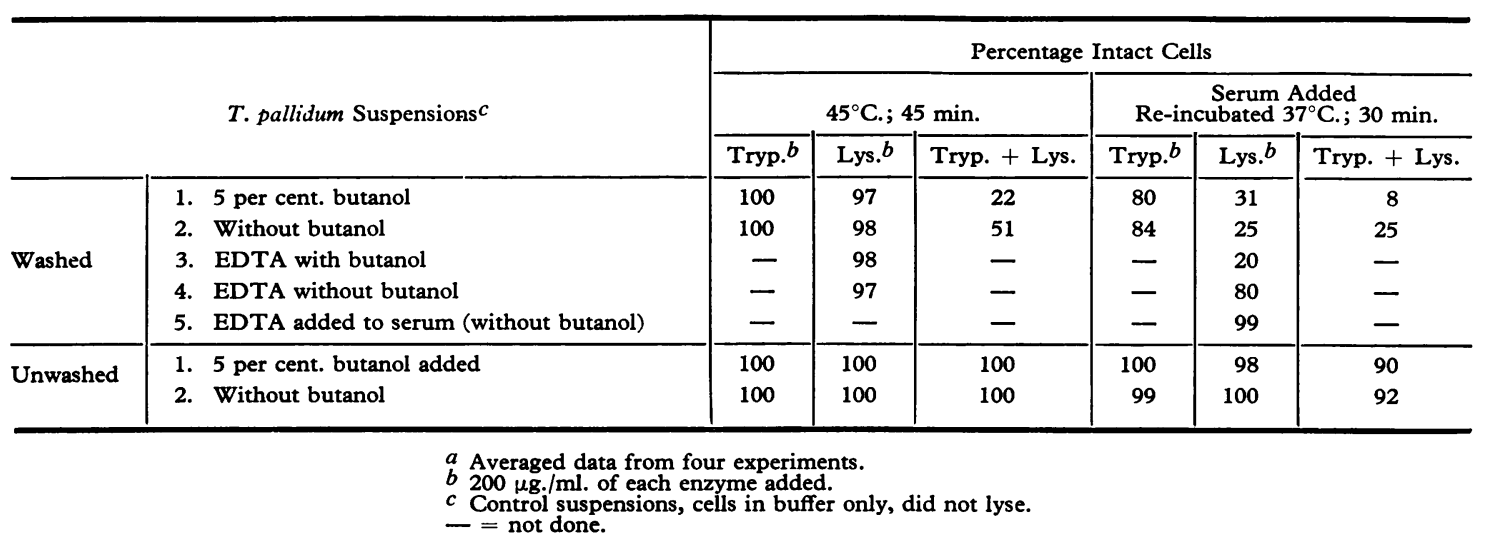

In separate experiments, spirochaetes were treated with lysozyme, or were trypsinized at $45^{\circ} \mathrm{C}$. for 45 minutes, and about 90 to 95 per cent. remained intact. Upon the addition of either trypsin or lysozyme to the mixture containing the other enzyme, and re-incubation at $45^{\circ} \mathrm{C}$. for the same time, only about 14 to 25 per cent. remained intact.

An electron micrograph of a trypsinized cell is shown in Fig. 1(d, opposite). The outer envelope of this cell appears to have been lost. Only remnants of it can be seen near the protoplasmic cylinder. The surface of the protoplasmic cylinder seems undamaged, although some loss of internal materials may have occurred. In contrast, a lysozyme-treated cell Fig. 1(e, overleaf) has an apparently intact outer envelope. The surface of the protoplasmic cylinder, however, is no longer clearly defined, and the internal material seems mottled. Fig. 1 ( $f$, overleaf), a lysozyme-treated cell at a higher magnification, emphasizes the degradation of the protoplasmic cylinder without apparent damage to the outer envelope.

\section{Discussion}

The presence of host-derived materials on the surfaces of pathogenic treponemes has been inferred by Christiansen (1963) from the works of several investigators. This author hypothesized that the host material was a slimy layer that protected the organisms from host defence mechanisms. Immunofluorescent testing in the present report indicated that the outermost material on the surfaces of unwashed $T$. pallidum included a rabbit globulin, since measurable fluorescence could be demonstrated with a goat anti-rabbit-globulin conjugate. Such fluorescence was not demonstrable after centrifugation at $15,000 \times \mathrm{g}$ and re-suspension of the cells in fresh buffer. A comparison of the electron micrographs Figs $1(a)$ and $1(b)$ also suggests the loss of a material relatively dense to the electron beam from the surface of the washed cell. Unless they were washed, the spirochaetes remained remarkably resistant to degradation by any of the methods used (Tables I and II).

After washing, it was possible to degrade $T$. pallidum enzymatically provided some form of pretreatment was carried out. The data in Table I, for example, indicate that freezing at $-20^{\circ} \mathrm{C}$. alters the cell structure in some manner; thus the cell becomes more susceptible to the lytic action of fresh guineapig serum. That the cell structure is in fact visibly altered by freezing may be seen in the electron micrograph [Fig. 1(c)]. The swelling and stretching of the outer envelope of the spirochaete is easily seen. No significant physical change is seen in the structure of the protoplasmic cylinder.

As has been shown previously with other spirochaetes (Nevin and Guest, 1967), when guinea-pig serum was inactivated with EDTA or by heating ( $56^{\circ} \mathrm{C}$.; $30 \mathrm{~min}$.) no lysis of pre-treated $T$. pallidum occurred. Serum treated with equimolar amounts of EDTA and $\mathrm{Ca}++$, however, retained its lytic action. It is most probable, therefore, that complement is also needed for the degradation of $T$. pallidum in fresh guinea-pig sera.

Trypsin and complement apparently act to achieve the same end-result on $T$. pallidum in that the presence of either material was required for degradation by lysozyme. For example, when cells were incubated at $45^{\circ} \mathrm{C}$. for $45 \mathrm{~min}$. with trypsin and lysozyme, about one-half of them were lysed. Similarly, upon incubation of active guinea-pig serum and re-incubation at $37^{\circ} \mathrm{C}$. for $30-45 \mathrm{~min}$., 


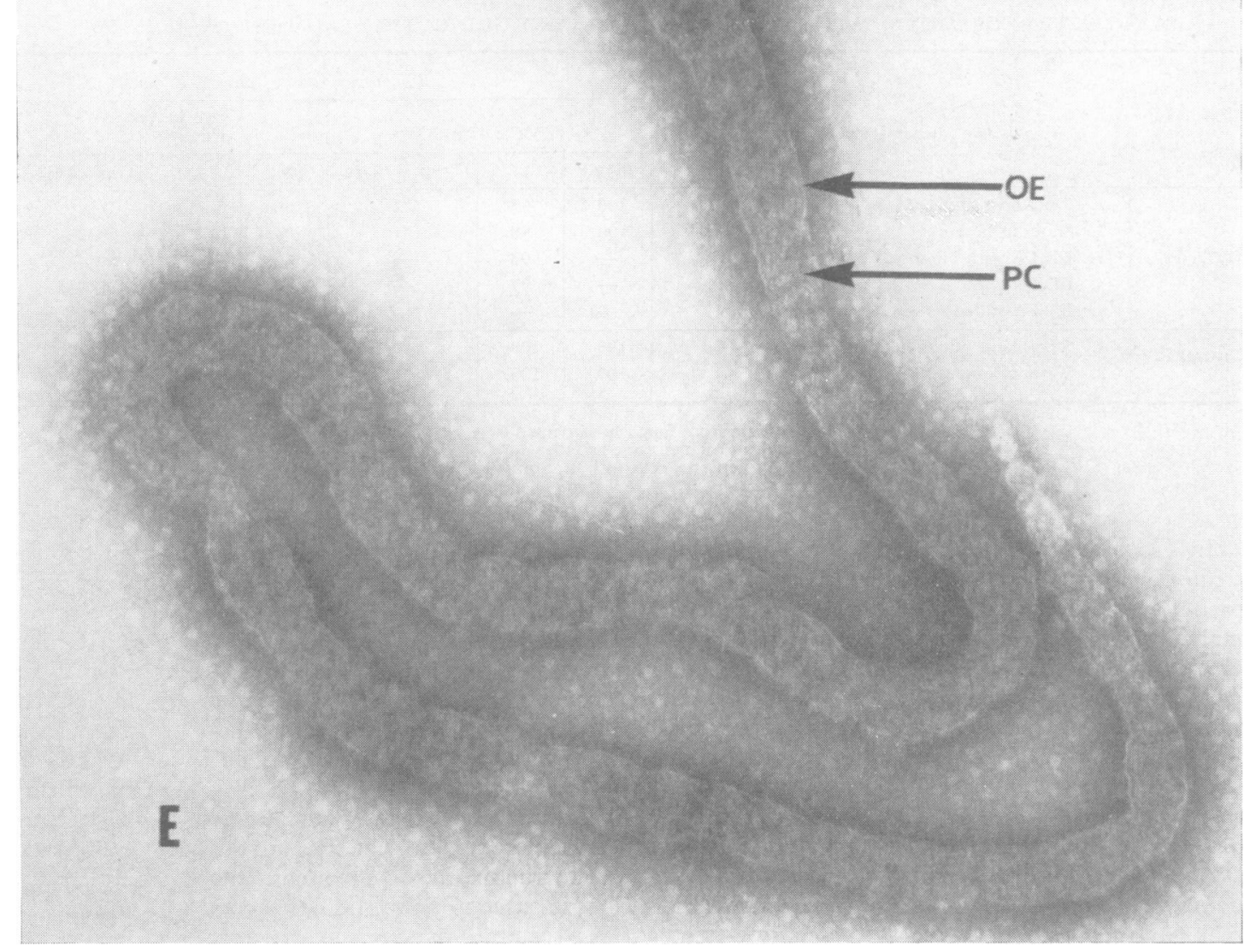

(e) A washed cell which had been incubated with lysozyme at $45^{\circ} \mathrm{C}$. for 45 minutes. $\times 52,100$. The outer envelope (OE) of the lysozyme-treated cell may be seen clearly, whereas the protoplasmic cylinder (PC) seems to have lost its structural integrity.

appreciable lysis occurred (Table II). It does not follow, however, that pre-treatment by freezing has the same effect as incubating at $45^{\circ} \mathrm{C}$. for 45 minutes, since cells incubated at this higher temperature did not lyse when treated with active guinea-pig serum (Table I and II). Neither was there evidence of damage when untreated washed cells were examined by electron micrography [Fig. 1(b)].

The enhancing effect of N-butanol may also be seen in Table II. Only about 22 per cent. of the cells remained intact when suspensions were incubated with butanol, trypsin, and lysozyme, but 51 per cent. remained intact when butanol was omitted. In similar experiments in which guinea-pig serum and cells pre-incubated with lysozyme were used, the results were 8 and 25 per cent. respectively. These are in general agreement with the observations of Noller and Hartsell (1961) concerning the effect of butanol on the lysis of certain Enterobacteriaceae. In this connexion it is interesting to point out that, upon the addition of guinea-pig serum to suspensions of $T$. pallidum pre-incubated with EDTA, lysozyme, and N-butanol, lysis was almost complete, whereas it was not extensive when butanol was omitted from the mixture (Table II). N-butanol obviously aids in making the cell more susceptible to attack by lysozyme and complement; however, this observation has not been pursued further.

The electron micrograph of $T$. pallidum which had been subjected to tryptic digestion [Fig. $1(d)$ ] is similar to that presented by Swain (1955). Both indicate a rather badly damaged cell envelope, and an apparently intact protoplasmic cylinder. Swain, however, used unwashed cells and noted (as also observed by us) that most of them resisted tryptic digestion for up to an hour. He, therefore, considered 


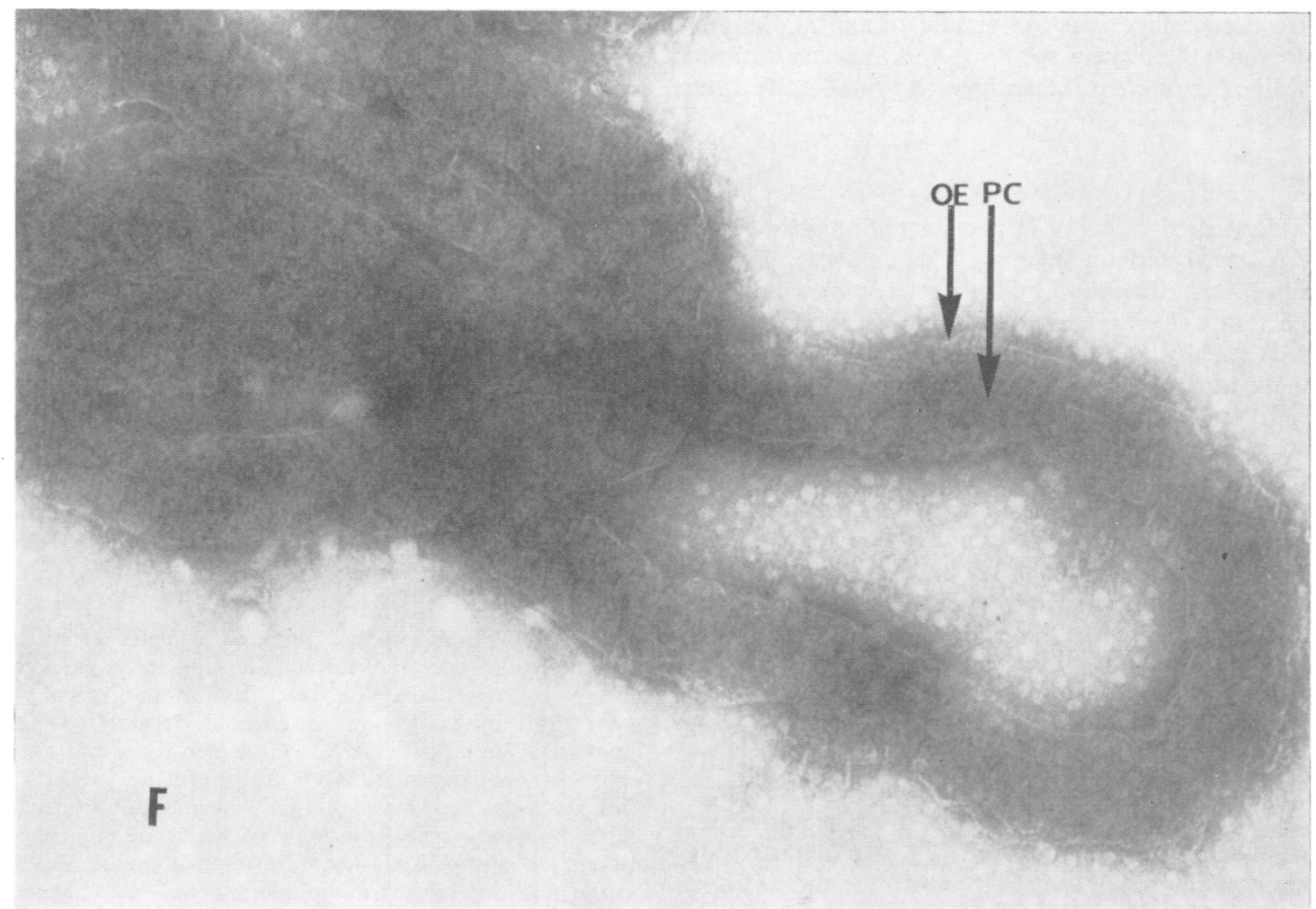

(f) A lysozyme-treated cell at higher magnification. $\times \mathbf{7 7 , 0 0 0}$. Again, the outer envelope is distinct whereas the protoplasmic cylinder has no apparent boundary

his picture to be that of a cell which had been ruptured accidentally, or of one which had been plasmoptyzed. In view of Fig. $1(d)$, it seems equally probable that he may have observed a result of tryptic digestion.

The envelope of the cell digested with lysozyme [Fig. 1(e)] appears relatively undisturbed, but the boundary of the protoplasmic cylinder is no longer clearcut, and the internal structure of the cylinder seems degraded. The action of lysozyme on Borrelia vincentii, in the presence of complement, also seems limited to the protoplasmic cylinder, which appeared to be degraded during the early stages of digestion leaving an apparently hollow cell when examined by darkfield microscopy (Nevin and Guest, 1967).

In studies of the Reiter treponeme, Pillot (1965) determined that the materials which could be made soluble with trypsin or pepsin were more highly concentrated in the cell envelope ( 44.4 per cent.) than in the protoplasmic cylinder (23.4 per cent.). Conversely, the muramic acids were found only in association with the protoplasmic cylinder. The electron micrographs of $T$. pallidum cells which had been trypsinized [Fig. 1(d)] or digested with lysozyme [Fig. 1(e)] generally agree with Pillot's observations, since the trypsinized cell has little or no envelope, and the lysozyme-treated cell no longer has an intact cylinder.

These observations suggest a means of determining the chemical nature of the various sub-cellular structures in spirochaetes. For example, the outer envelope is probably a lipoprotein complex since trypsin digests it and N-butanol, a lipid solvent, effects undefined changes in it. Trypsin is known to have esterase, as well as endopeptidase, activity (Neurath and Schwert, 1950) and could have mediated both proteolysis and lipolysis in the absence of the alcohol (Table II). The first component of complement is known to have esterase activity (Ratnoff and Lepow, 1957); therefore explanation of its role in spirochaetolysis may also be related to a lipoprotein envelope. Furthermore, these observations suggest a somewhat different approach to studies of immunity in spirochaetal 
infections, since it is reasonable to expect the employment of enzyme-substrate specificity as a means of altering in vitro the antigenicity of the infectious agents.

\section{Summary}

Unwashed $T$. pallidum propagated in rabbit testes were not lysed under any of several experimental conditions. Immunofluorescent testing indicated the removal of material containing rabbit globulin from such cells by washing them in $0.003 \mathrm{M}$ phosphate buffer $(\mathrm{pH} 7 \cdot 3)$. Electron micrographs also indicated the loss of some material occluded on the outer surfaces of the spirochaete, as a result of washing. After washing, lysis could be effected by freezing at $-20^{\circ} \mathrm{C}$, , then incubating with active guinea-pig serum. Lysis was also effected by incubation with trypsin and lysozyme at $45^{\circ} \mathrm{C}$. Similarly, spirochaetolysis occurred when cells that had been pre-incubated with lysozyme at $45^{\circ} \mathrm{C}$. were then incubated with active complement (guinea-pig serum) at $37^{\circ} \mathrm{C}$. Both of these reactions were enhanced by N-butanol, whereas no lysis occurred if the complement was inactivated by heat or EDTA.

Electron micrographs revealed mechanical damage to the outer envelopes of spirochaetes which had been frozen at $-20^{\circ} \mathrm{C}$. Trypsin digested the outer envelope, leaving the protoplasmic cylinder apparently undamaged. Conversely, lysozyme attacked the protoplasmic cylinder, leaving the outer envelope relatively undisturbed.

\section{REFERENCES}

Bradfield, J. R. G., and Cater, D. B. (1952). Nature (Lond.), 169, 944.

Caulfield, J. B. (1957). F. biophys. biochem. Cytol., 3, 827.

Christiansen, S. (1963). Lancet, 1, 423.

Communicable Disease Center, U.S. Department of Health, Education, and Welfare (1964). "Serologic Tests for Syphilis," (rev. ed.). U.S. Public Health Service Publication No. 411 Government Printing Office, Washington, D.C.

Deacon, W. E., and Hunter, E. F. (1962). Proc. Soc. exp. Biol. (N.Y.), 110, 352.
Kellenberger, E., Ryter, A., and Sechaud, J. (1958). F. biophys. biochem. Cytol., 4, 671 .

Kent, J. F., and DeWeerdt, J. B. (1963). Brit. F. vener. Dis., 39, 37.

Levine, L., Cowan, K. M., Osler, A. G., and Mayer, M. M. (1953). F. Immunol., 71, 359, 367.

Listgarten, M. A., Loesche, W. J., and Socransky, S. S. (1963). F. Bact., 85, 932.

Metzger, M., Hardy, P. H., and Nell, E. E. (1961). Amer. F. Hyg., 73, 236:

Neurath, H., and Schwert, G. W. (1950). Chem. Rev., 46, 69.

Nevin, T. A., and Guest, W. J. (1967). F. Bact., 94, 1388.

Noller, E. C., and Hartsell, S. E. (1961). Ibid., 81, 482.

Pillot, J. (1965). Thesis, University of Paris, France.

Ratnoff, O. D., and Lepow, I. H. (1957). F. exp. Med., $106,327$.

Swain, R. H. A. (1955). F. Path. Bact., 69, 117.

\section{L'effet lytique de la trypsine, de la lysozyme et du complément sur le Treponema pallidum \\ RÉSUMÉ}

Des $T$. pallidum non-lavés propagés dans les testicules du lapin n'ont pas été lysés sous n'importe quelle condition expérimentale. Le test immunofluorescent a indiqué qu'une substance contenant de la globuline du lapin avait été enlevée de ces cellules en les lavant avec

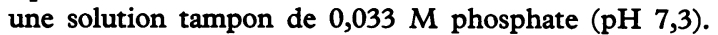
Des micrographes électroniques ont aussi indiqué la perte d'un peu d'une substance occlusive de la surface externe des spirochètes, due au résultat du lavage. Après lavage la lyse pouvait être faite par le gel à $-20^{\circ} \mathrm{C}$., suivi d'incubation avec du sérum actif de cobaye. La lyse pouvait aussi être obtenue par l'incubation avec de la trypsine et la lysozyme à $45^{\circ} \mathrm{C}$. De même la spirochétolyse avait lieu quand les cellules qui avaient été incubées auparavant avec de la lysozyme à $45^{\circ} \mathrm{C}$. étaient alors incubées avec du complément actif (du sérum de cobaye) à $37^{\circ} \mathrm{C}$. Ces deux réactions avaient été augmentées par du N-butanol, tandis qu'aucune lyse n'avait eu lieu si le complément avait été inactivé par la chaleur ou par le EDTA.

Les micrographes électroniques avaient révélé des dommages aux enveloppes externes des spirochètes qui avaient été gelés à $-20^{\circ} \mathrm{C}$. La trypsine avait digéré l'enveloppe externe laissant le cylindre protoplasmique apparemment non-endommagé. Réciproquement la lysozyme avait attaqué le cylindre protoplasmique laissant l'enveloppe externe relativement intacte. 